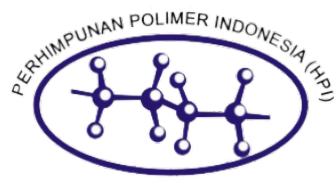

\title{
Pembuatan Hidrogel Berbahan Dasar Polietilena Glikol-Kitosan menggunakan Iradiasi Berkas Elektron
}

\author{
Farah Nurlidar $^{\mathrm{a}}$, , Arif Rachmanto $^{\mathrm{a}}$, Darmawan Darwis ${ }^{\mathrm{a}}$ \\ Hidrogel polietilena glikol (PEG)-kitosan dibuat menggunakan iradiasi berkas elektron pada dosis 10-50 kGy. Karakterisasi \\ fisika kimia hidrogel, seperti identifikasi gugus fungsional, fraksi gel dan kapasitas absorpsi akan dianalisis. Hasil analisis \\ fraksi gel menunjukkan jumlah hidrogel yang terbentuk meningkat dengan naiknya dosis iradiasi $(p<0,0001)$. Gugus \\ fungsional pada hidrogel dianalisis menggunakan spektroskopi Fourier Transform Infra-Red (FTIR). Spektra FTIR hidrogel \\ menunjukkan adanya puncak serapan khas gugus fungsi-gugus fungsi dari PEG dan kitosan, menunjukkan keberadaan \\ PEG dan kitosan dalam struktur tiga dimensi (3D) hidrogel. Hidrogel PEG-kitosan 10 kGy memberikan nilai kapasitas \\ absorpsi yang tinggi hingga 6,7 kali berat awalnya. Hidrogel PEG-kitosan sangat berpotensi untuk diaplikasikan sebagai \\ matriks 3D pada sistem penghantaran obat.
}

Received

10 October 2018

Received in revised form

Accepted

28 December 2018

Published

28 June 2019

DOI: $10.37889 / \mathrm{mpi} .2019 .22 .1 .3$
Poly(ethylene glycol) (PEG)-chitosan hydrogels were prepared using an electron beam at 10-50 kGy of irradiation dose. The physical and chemical characterization of the hydrogel, such as functional groups identification, gel fraction, and water absorption capacity of the hydrogels were then investigated. The presence of functional groups on the hydrogel was confirmed using Fourier Transform Infra-Red (FTIR) spectroscopy. The FTIR spectra of the hydrogels showed the presence of specific functional groups that are correlated to PEG and chitosan, indicating the formation of 3D network between PEG and chitosan. The hydrogel of PEG-chitosan $10 \mathrm{kGy}$ showed a high swelling ratio of up to 6.7 times its initial weight. This hydrogel showed the potential to be applied as a 3D scaffolds in drug delivery system.

Kata kunci: Berkas elektron, hidrogel, kitosan, matriks 3D, polietilena glikol.

\section{Pendahuluan}

Saat ini, hidrogel banyak dikembangkan sebagai matriks tiga dimensi (3D) pada sistem penghantaran obat (drug delivery system). ${ }^{1-3}$ Pemilihan karakteristik hidrogel yang tepat, seperti sifat permukaan hidrogel, stabilitas hidrogel, kapasitas absorpsi, serta kapasitas pelepasan obat, sangat diperlukan dalam mendukung keberhasilan penghantaran obat menggunakan hidrogel. ${ }^{1}$ Sistem penghantaran obat menggunakan hidrogel memberikan beberapa keuntungan, di antaranya: hidrogel berfungsi sebagai pelindung obat dari lingkungan fisiologi tubuh, seperti kondisi asam dan keberadaan enzim yang ada dalam tubuh. ${ }^{1-3}$

Kebanyakan hidrogel dibuat dengan menggunakan metode pembentukan ikatan silang secara kimia dikarenakan akan menghasilkan hidrogel dengan sifat mekanik yang tinggi dan stabil dalam jangka waktu yang lama..$^{1,3,4}$ Akan tetapi, metode ini membutuhkan inisiator kimia yang bersifat toksik. ${ }^{3-4}$ Oleh karena itu, teknik pembentukan ikatan silang dalam pembuatan hidrogel perlu diperhatikan agar diperoleh hidrogel yang biokompatibel, dan tidak toksik.

Iradiasi menggunakan berkas elektron dan sinar gamma diketahui dapat mengatasi permasalahan penggunaan inisiator

\footnotetext{
a. Center for Application of Isotopes and Radiation, National Nuclear Energy Agency, Jl. Lebak Bulus Raya, No. 49, Jakarta Selatan 12440, Indonesia

† Corresponding author: farah@batan.go.id.
}

kimia. ${ }^{5-7}$ Keunggulan teknik ini di antaranya: tidak memerlukan inisiator kimia, waktu iradiasi yang singkat, dan sifat fisika kimia hidrogel dapat dengan mudah dikontrol dengan mengatur laju dosis, dosis iradiasi, dan konsentrasi polimer sebagai bahan dasar pembuatan hidrogel..$^{5-7}$

Pada penelitian ini akan dibuat hidrogel berbahan dasar PEG dan kitosan dengan menggunakan iradiasi berkas elektron. PEG dan kitosan telah banyak digunakan sebagai bahan dasar pembuatan biomaterial untuk aplikasi bidang kesehatan. ${ }^{8-10}$ Material berbahan dasar PEG telah disetujui oleh US Food and Drug Administration untuk digunakan secara klinis karena bersifat non-toksik dan non imunogenik. ${ }^{8-9}$ Kitosan adalah natural polimer yang banyak digunakan dalam bidang farmasi karena biokompatibel. ${ }^{10}$

Pada penelitian ini akan dipelajari kemungkinan penggunaan hidrogel tersebut pada sistem penghantaran obat dengan melakukan uji kapasitas penyerapan hidrogel pada beberapa larutan buffer. Selain itu, pada penelitian ini juga akan dilakukan karakterisasi fisika kimia yaitu uji fraksi gel dan analisis gugus fungsi menggunakan alat spektrofotometer Fourier Transform Infra-Red (FTIR).

\section{Metode Percobaan}

\section{Alat dan Bahan}

Polietilena glikol diakrilat dan kitosan dibeli dari Sigma-Aldrich. Buffer pH 2 dan 7 dibeli dari Merck. Semua bahan kimia digunakan langsung tanpa pemurnian lebih lanjut. 


\section{Pembuatan Hidrogel PEG-Kitosan}

Hidrogel PEG-kitosan dibuat dengan mencampur larutan PEGDA dan kitosan. Larutan PEGDA (20\%) dalam air ditambahkan ke dalam larutan kitosan $(1 \% \mathrm{~b} / \mathrm{v}$ dalam $0,05 \mathrm{M} \mathrm{HCl})$ dan diaduk perlahan. Konsentrasi akhir PEGDA dan kitosan dalam larutan adalah masingmasing 10 and 0,5\%. Empat puluh mikroliter larutan campuran tersebut kemudian diteteskan ke dalam cetakan silikon (diameter lubang $=5 \mathrm{~mm}$, tinggi $=3 \mathrm{~mm}$ ) yang telah dialasi microscope glass coverslips. Cetakan berisi larutan PEGDA-kitosan tersebut kemudian ditempatkan di dalam plastik, dikemas dan diiradiasi menggunakan mesin berkas elektron $2 \mathrm{MeV}$ yang ada di Pusat Aplikasi Isotop dan Radiasi, Kawasan Nuklir Pasar Jumat, Jakarta Selatan. Dosis iradiasi yang diberikan pada larutan adalah 10, 20, 30, 40 dan 50 kGy (laju dosis $\left.=10 \mathrm{kGy}_{\text {pass }}{ }^{-1}\right)$.

\section{Fraksi Gel Hidrogel PEG-Kitosan}

Hidrogel PEG-kitosan yang diperoleh dikeringkan menggunakan alat freeze-dryer dan ditimbang $\left(\mathrm{W}_{0}\right)$. Hidrogel kering kemudian dimasukkan ke dalam tabung gelas berukuran $5 \mathrm{~mL}$ yang berisi $2 \mathrm{~mL}$ air demineralisasi dan diinkubasi pada kecepatan $60 \mathrm{rpm}$ selama 24 jam menggunakan inkubator goyang (Incushaker, Benchmark Scientific; USA). Selama inkubasi, air demineralisasi diganti sebanyak 4 kali. Hidrogel selanjutnya dicuci menggunakan air demineralisasi dan dikeringkan menggunakan alat freeze-dryer $\left(\mathrm{W}_{\mathrm{i}}\right)$. Fraksi gel dihitung dengan menggunakan rumus:

Fraksi gel $=\frac{\mathrm{w}_{\mathrm{i}}}{\mathrm{w}_{0}} \times 100 \%$

\section{Kapasitas Penyerapan Hidrogel PEG-Kitosan}

Kapasitas penyerapan air hidrogel dilakukan dengan merendam hidrogel kering $\left(\mathrm{W}_{0}\right)$ pada buffer $\mathrm{pH} 2$ dan 7 pada suhu $37^{\circ} \mathrm{C}$ di dalam inkubator goyang. Setelah beberapa waktu perendaman, hidrogel diangkat, dilap perlahan menggunakan kertas saring dan ditimbang $\left(\mathrm{W}_{\mathrm{t}}\right)$. Kapasitas penyerapan air dihitung menggunakan rumus berikut ini:

Kapasitas serap (\%) $=\frac{\left(w_{t}-w_{0}\right)}{w_{0}} \times 100 \%$

\section{Spektroskopi Inframerah Hidrogel PEG-Kitosan}

Identifikasi gugus fungsi pada hidrogel PEG-kitosan dilakukan menggunakan alat spektrofotometer (Shimadzu, Jepang) dengan metode $\mathrm{KBr}$, pada rentang bilangan gelombang $400-4000 \mathrm{~cm}^{-1}$, jumlah scan $=16$ dan resolusi $1 \mathrm{~cm}^{-1}$.

\section{Uji Statistik}

Uji statistik dilakukan menggunakan software KaleidaGraph 4.5 (Synergy Software, Reading, PA, USA) yang diikuti dengan uji perbedaan signifikan. Nilai $p<0,05$ dianggap berbeda secara signifikan.

\section{Hasil dan Pembahasan}

\section{Pembuatan Hidrogel PEG-Kitosan}

Hidrogel PEG-kitosan dibuat dengan mengiradiasi larutan campuran antara PEGDA dan kitosan menggunakan berkas elektron (Gambar 1). Pembentukan hidrogel disebabkan terjadinya reaksi antara radikal-radikal yang terbentuk selama proses iradiasi berlangsung. Radikal-radikal yang terbentuk terutama berasal dari reaksi hidrolisis air, seperti radikal hidroksil $\left(\mathrm{OH}^{-}\right)$dan elektron terhidrasi (e- aq). ${ }^{6,11}$ Radikal-radikal tersebut dapat menyerang rantai polimer sehingga menghasilkan makroradikal PEGDA dan kitosan. ${ }^{12}$ Rekombinasi makroradikal-makroradikal tersebut dapat menghasilkan ikatan silang antara kitosan dan PEGDA. ${ }^{12}$

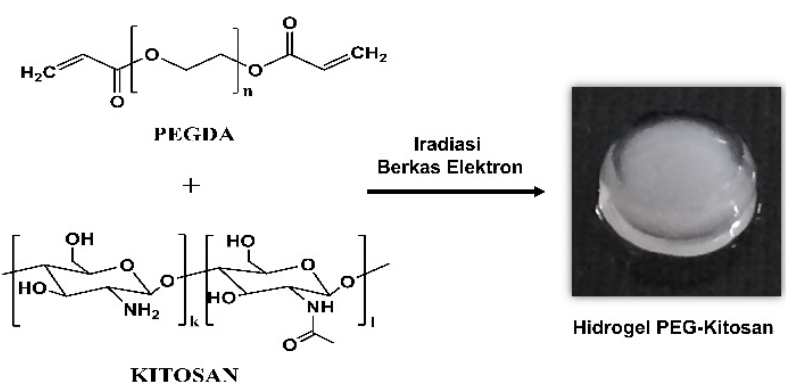

Gambar 1. Pembuatan hidrogel PEG-Kitosan (diameter hidrogel = 3 $\mathrm{mm})$.

Proses pembentukan gel pada hidrogel PEG-kitosan dikuantifikasi menggunakan fraksi gel (Gambar 2). Fraksi gel menunjukkan rasio jumlah PEG-kitosan dalam hidrogel dibandingkan dengan jumlah larutan awal PEG-kitosan sebelum iradiasi. ${ }^{13}$ Hasil menunjukkan bahwa nilai fraksi gel hidrogel PEG-Kitosan meningkat dengan meningkatnya dosis iradiasi $(p<0,0001)$. Nilai fraksi gel tertinggi diperoleh pada larutan PEG-kitosan yang diiradiasi pada dosis $50 \mathrm{KGy}$ yaitu $96,9 \pm 5,37 \%$. Peningkatan dosis iradiasi akan menyebabkan naiknya jumlah radikal yang akan menginisiasi terbentuknya ikatan silang. Semakin tinggi dosis iradiasi, semakin banyak jumlah ikatan silang yang terbentuk.

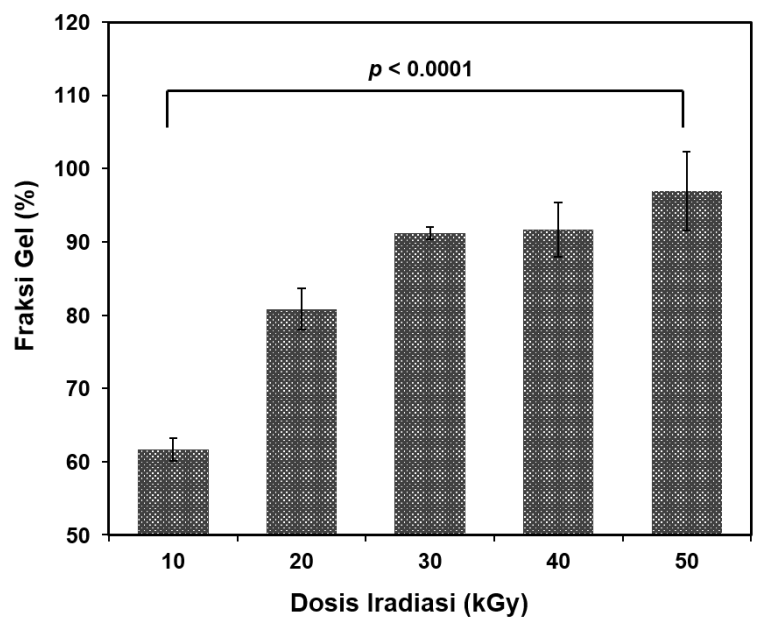

Gambar 2. Fraksi gel hidrogel PEG-kitosan.

\section{Spektroskopi Inframerah Hidrogel PEG-Kitosan}

Identifikasi gugus fungsi yang terdapat pada hidrogel PEG-kitosan dilakukan menggunakan alat FTIR. Sebagai pembanding digunakan kitosan dan hidrogel PEGDA 10 kGy (Gambar 3). Spektrum FTIR hidrogel PEGDA menunjukkan puncak pada bilangan gelombang 2881 dan $1725 \mathrm{~cm}^{-1}$ yang merupakan serapan khas vibrasi gugus $\mathrm{C}-\mathrm{H}$ dan vibrasi ulur gugus karbonil pada PEGDA. Puncak yang sama juga terdapat pada spektra FTIR hidrogel PEG-kitosan 10 dan 50 kGy. 


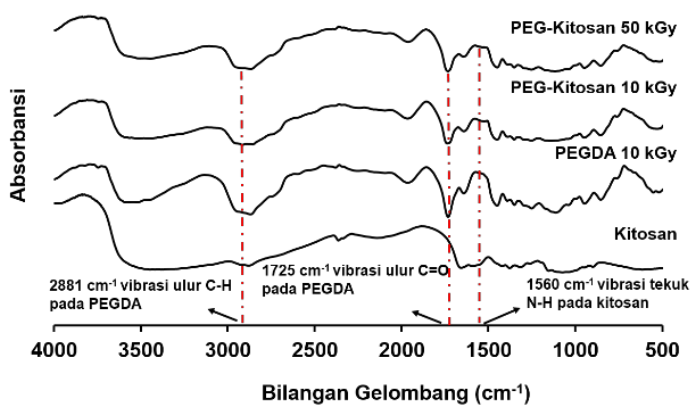

Gambar 3. Spektra FTIR kitosan, hidrogel PEGDA dan hidrogel PEGkitosan.

Spektrum FTIR kitosan memberikan puncak serapan pada 1560 $\mathrm{cm}^{-1}$ yang merupakan serapan khas vibrasi tekuk gugus $\mathrm{N}-\mathrm{H}$ pada kitosan. ${ }^{14}$ Spektrum FTIR hidrogel PEG-kitosan juga memberikan puncak pada bilangan gelombang yang sama, walaupun tidak terlihat tajam. Hasil tersebut menunjukkan bahwa hidrogel yang terbentuk mengandung PEG dan kitosan.

\section{Kapasitas Penyerapan Hidrogel PEG-Kitosan}

Kapasitas penyerapan air merupakan salah satu parameter penting untuk matriks 3D pada sistem penghantaran obat karena berhubungan dengan kemampuan penetrasi obat pada saat dienkapsulasi ke dalam hidrogel dan pada saat pelepasan obat. ${ }^{1,15}$ Pada penelitian ini, kapasitas penyerapan hidrogel dilakukan pada $\mathrm{pH} 2$ dan 7. Hasil menunjukkan kapasitas penyerapan hidrogel pada $\mathrm{pH} 2$ dan 7 memberikan kecendrungan yang sama, yaitu kapasitas penyerapan menurun dengan naiknya dosis iradiasi (pada $t=300$ menit, $p<0,05$ pada $\mathrm{pH} 2$ dan $\mathrm{p}<0,01$ pada $\mathrm{pH} 7$ ). Hasil ini sesuai dengan nilai fraksi gel yang didapatkan pada penelitian ini. Peningkatan dosis iradiasi akan meningkatkan jumlah pembentukan ikatan silang, sehingga membatasi difusi molekul air pada hidrogel. ${ }^{15}$
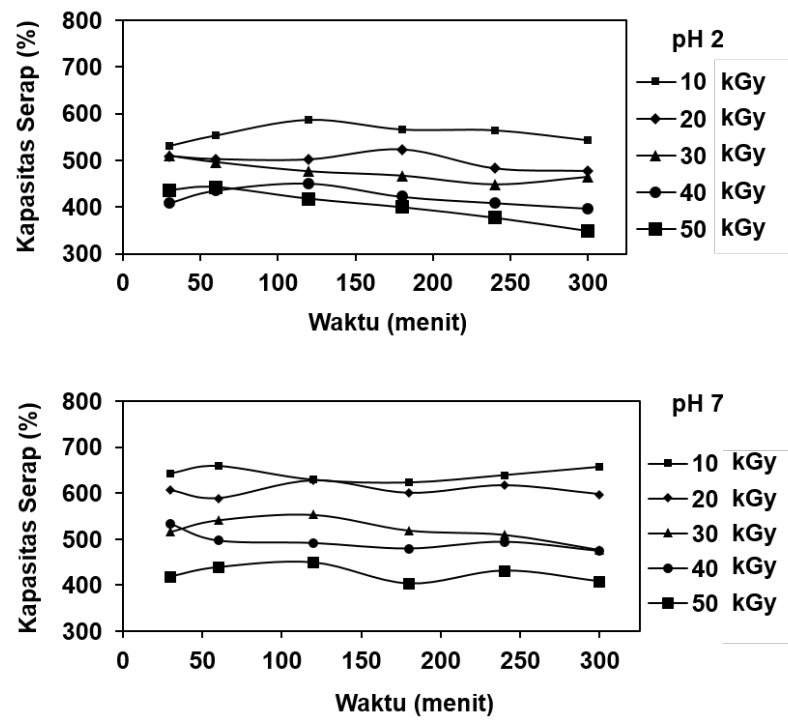

Gambar 4. Kapasitas absorpsi hidrogel PEG-kitosan pada buffer $\mathrm{pH}$ 2 dan $\mathrm{pH} 7$.
Hidrogel PEG-kitosan 10 kGy memiliki kapasitas absorpsi yang tinggi sekitar $670 \%$. Hal ini menunjukkan bahwa hidrogel PEG-kitosan berpotensi untuk digunakan sebagai matriks 3D pada sistem penghantaran obat. Pada penelitian selanjutnya, akan diteliti lebih lanjut mengenai enkapsulasi obat dalam hidrogel PEG-kitosan dan mekanisme pelepasan obat terenkapsulasi secara in vitro.

\section{Kesimpulan}

Hidrogel PEG-kitosan telah berhasil dibuat menggunakan iradiasi berkas elektron pada dosis 10-50 kGy. Hidrogel PEG-kitosan 10 kGy memiliki kapasitas penyerapan tertinggi hingga sekitar $670 \%$ berat awalnya, sehingga berpotensi untuk digunakan sebagai matriks 3D pada sistem penghantaran obat.

\section{Ucapan Terima Kasih}

Penelitian ini dibiayai sebagian oleh dana DIPA Pusat Aplikasi Isotop dan Radiasi, Badan Tenaga Nuklir Nasional.

\section{Referensi}

1 J. Li, D.J. Mooney, Designing hydrogels for controlled drug delivery, Nature Reviews Material, 2016, 1, 16071.

2 Y. Wang, J. Wang, Z. Yuan, H. Han, T. Li, L. Li dan X. Guo, Chitosan cross-linked poly(acrylic acid) hydrogels: drug release control and mechanism, Colloid and Surfaces B: Biointerfaces, 2017, 152, 252-259.

3 G. Jiang, J. Sun dan F. Ding, PEG-g-chitosan thermosensitive hydrogel for implant drug delivery: cytotoxicity, in vivo degradation and drug release, J. Biomaterials Sci, Polym. Ed., 2014, 25(3), 241-256.

4 Y. Xia, Y. Zhou, Q. Dong, H. Yang, X. Liu, S. Gu, Y. Tao, Z. Bai, D. Ye dan W. Xu, Photopolymerized Injectable Water-soluble maleilated chitosan/poly(ethylene glycol) diacrylate hydrogels as potential tissue engineering scaffolds, J. Photopolym. Sci. Tecnol., 2017, 30(1), 33-40.

5 M.H. Kim, B.S. Kim, J. Lee, D. Cho, O.H. Kwon dan W.H. Park, Silk fibroin/hydroxyapatite composites hydrogel induced by gamma-ray irradiation for bone tissue engineering, Biomaterial Research, 2017, 21(12).

6 E.M. Ahmed, Hydrogel: preparation, characterization, and applications: a review, J. adv. Res., 2015, 6(2), 105-121.

7 J. Maitra, V.K. Shukla, Cross-linking in hydrogels - a review, American Journal of Polymer Science, 2014, 4(2), 25-31.

8 X. Kong, Q. Tang, X. Chen, Y. Tu, S. Sun dan Z. Sun, Polyethylene glycol as a promising synthetic material for repair of spinal cord injury, Neural Regen. Res., 2017, 12(6), 1003-1008.

9 A.A. D'souza dan R. Shegokar, Polyethylene glycol (PEG): a versatile polymer for pharmaceutical applications, Expert Opinion on Drug delivery, 2016, 13(9), 1257-1275.

10 S. Naskar, K. Koutsu dan S. Sharma, Chitosan-based nanoparticles as drug delivery systems: a review on two decades of research, $J$. Drug Targeting, 2018, doi: 10.1080/1061186x.2018.1512112.

11 M. Trojanowicz, K. Bobrowski, T. Szreder dan A. BojanowskaCzajka, Advanced Oxidation Processes for Waste Water Treatment: 
Chapter 9-Gamma-ray, X-ray and electron beam based processes, 2018, 257-331.

12 R. Czechowska-Biskup, R.A. Wach, P. Stojek, M. Kamińska, J.M. Rosiak, P. Ulański, Synthesis of chitosan and carboxymethyl chitosan hydrogels by electron beam irradiation, Progress of Chemistry and Application of Chitin and Its Derivatives, 2016, XXI, 27-45, doi: 10.15259/PCACD.21.03.

13 F. Nurlidar, K. Yamane, M. Kobayashi, K. Terada, T. Ando dan M. Tanihara, Calcium deposition in photocrosslinked poly(Pro-Hyp-
Gly) hydrogels encapsulated rat bone marrow stromal cells, J. Tissue Eng. Regen. Med., 2018, 12(3), e1360-e1369.

$14 \mathrm{~S}$. Jung dan H. Yi, Fabrication of chitosan-poly(ethylene glycol) hybrid hydrogel microparticles via replica molding and its application toward gacile conjugation of biomolecules, Langmuir, 2012, 28, 17061-17070.

15 B.S.F. Cury, A.D. Castro, S.I. Klein, et al., Modeling a syatem of phosphated cross-linked high amylose for controlled drug release. Part 2: physical parameter, cross-linking degrees and drug delivery relationships, Int. J. Pharm., 2009, 371, 8-15. 